\title{
Melted Device
}

National Cancer Institute

\section{Source}

National Cancer Institute. Melted Device. NCI Thesaurus. Code C62908.

Problem associated with a solid device being transformed into a molten or liquid state. 